Article

\title{
Elevated Blood Lead Levels in Children Associated with Living near Mining Waste Sites in Guerrero/Mexico
}

\author{
María de Lourdes Soto-Ríos ${ }^{1, *}$, Cuauhtémoc Arturo Juárez-Pérez ${ }^{2}$, \\ Francisco Javier Rendón-Gandarilla ${ }^{1}$, Oscar Talavera-Mendoza ${ }^{3}$ and Guadalupe Aguilar-Madrid ${ }^{2}$ \\ 1 Centro Regional de Educación Superior, Campus Zona Norte, Universidad Autónoma de Guerrero, \\ Taxco Guerrero C.P. 40323, Mexico; fjrgandarilla@gmail.com \\ 2 Coordinación de Salud en el Trabajo, Instituto Mexicano del Seguro Social (IMSS), \\ México DF, C. P. 06760, Mexico; carturojp@gmail.com (C.A.J.-P.); gpeaguilarm@gmail.com (G.A.-M.) \\ 3 UA de Ciencias de la Tierra, Universidad Autónoma de Guerrero, Exhacienda S. Juan Bautista, \\ Taxco el Viejo, Guerrero C.P. 40323, Mexico; talavera@geo.arizona.edu \\ * Correspondence: joelulu@prodigy.net.mx; Tel.: +52-77-7313-9035
}

Academic Editor: Andrea Cattaneo

Received: 26 March 2017; Accepted: 8 June 2017; Published: 12 June 2017

\begin{abstract}
Blood lead levels (BLL) in children are associated with lead in soil and represent a major public health problem; however, there are few reports of lead contamination related to mining waste sites in Mexico. Therefore, we conducted a cross-sectional study in the State of Guerrero to identify the association between proximity of residence to mining site waste and BLL in children. The impact of the different variables related to BLL were analyzed with logistic regression. Geometric mean BLL was $13.6 \mu \mathrm{g} / \mathrm{dL}, 15.9 \mu \mathrm{g} / \mathrm{dL}$ in communities proximal to waste sites and $5.5 \mu \mathrm{g} / \mathrm{dL}$ in a distant control community. Children living in communities near the mining waste have higher BLL that children living in communities far away from the waste. Our results are similar to studies in other countries and indicate that mining waste sites remain an active source of BLL contamination that affect children's health.
\end{abstract}

Keywords: mining waste; lead contamination; blood lead levels; children exposure; Guerrero

\section{Introduction}

Lead exposure damages health, affecting mainly the nervous system and is associated with hyperactivity and attention and conduct problems [1]. Children are more vulnerable to the effects of lead, because their intestinal absorption is greater in the first years of life, and the hand-mouth pathway of contaminated particles in soil and dust is the most important lead entrance [2]. Main sources for lead in soil and dust include house paint, industrial emissions, and para-occupational exposure [3,4]. In Mexico, use of lead oxide-glazed ceramic ware for food preparation and storage has been an important source of lead ingestion [4,5]. Tailings of open air-deposited mining wastes also add lead to soil, household dust, and water supplies in the area. Mine tailings may thus be another industrial source of lead, as metallurgic industries, for the community residing in proximity to these waste areas. Studies of mining wastes and lead pollution in other countries state that mining wastes contribute to an increase in blood lead levels (BLL) in child populations, presenting a risk to their health [3,6-13].

In México, mining activity has been intensively developed since 1530. Among the mining states, Guerrero is a highly rich region in many natural resources that contributes $2 \%$ of the national production of minerals, mainly of $\mathrm{Au}$ and $\mathrm{Ag}$; however, mining wastes have been inadequately deposited near the mines and in proximity to communities. This inadequate treatment and disposal could provoke the exposure of contaminants to surrounding communities. Thus, we hypothesize that communities near the mining waste sites could be more exposed to lead exposure that will reflect 
in high BLL values in comparison with a far community. Although many mining waste sites have been analyzed as well as the surrounding communities, some regions such as Guerrero have a poor assessment of BLL determination or environmental lead contamination as a main exposure source. Therefore, the aim of this work was to determine the relation between the BLL and the distance from the mining waste sites in children from different communities in Guerrero.

\section{Materials and Methods}

\subsection{Communities Selection}

We carried out a cross sectional study in children from two sets of communities, one close and the other far, from a mining plant located south of Taxco, Guerrero, Mexico. From 1940 up to 1960, the mine generated approximately 2.5 million tons of deposits produced in the form of carbonates, sulfates, and oxides, and a lesser proportion as lead sulfide (galena). It has been extensively used for the acquisition of $\mathrm{Au}, \mathrm{Ag}, \mathrm{Pb}, \mathrm{Zn}$ and $\mathrm{Cu}$, and currently is inactive. Soil samples were recovered from mine tailings to determine lead concentrations $(n=25)$. Sampling unit sites were delimited with a satellite geographic positioning system (GPS) and by random selection of houses within each community. The distance between the sampling units and the exposure zone by topographic map was determined, selecting three near communities (A, B and C) and a far community (D). Communities were grouped according to distance from the mining waste site: community $\mathrm{A}$ was found at a distance of $0.1-5 \mathrm{~km}$, community $B$ at $0.2-5 \mathrm{~km}$, and community $C$ at a distance of $5-10 \mathrm{~km}$ from the mining waste site. The distance from the mining waste site for the non-exposed community (D) was $>35 \mathrm{~km}$ (Figure 1).

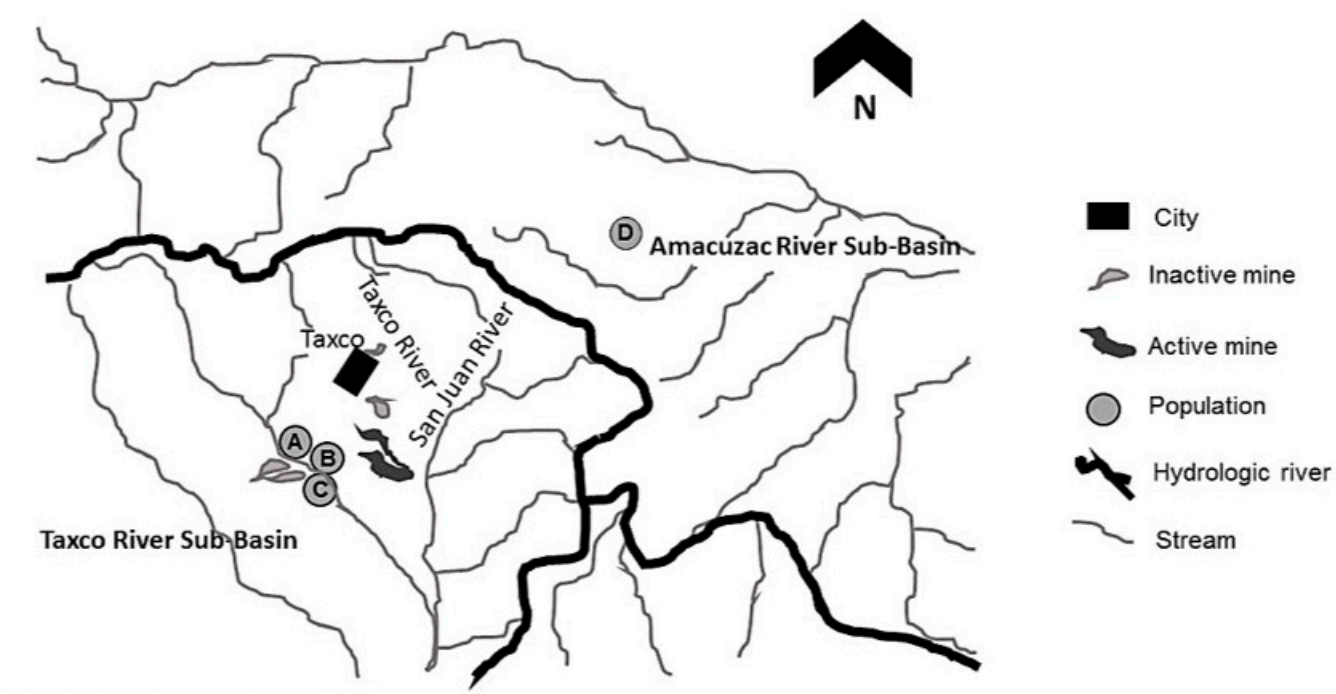

$119^{\circ} 13^{\prime} 12^{\prime \prime},-17^{\circ} 53^{\prime} 24^{\prime \prime} \mathrm{N}$

Figure 1. Communities distribution from the mining waste sites.

\subsection{Community Behavioral Analysis}

We applied a questionnaire to identify demographic characteristics and other lead exposure sources that include age, sex, years at present domicile, schooling, housing characteristics, use of lead-glazed ceramics for food cooking and storage, parental occupations (mine workers were not selected) and smoking habits, vehicular traffic characteristics, children's behavior such as putting objects into the mouth and soil ingestion, and location of play areas. Questionnaire was self-filled. Parents who worked in the mines were excluded from the research due to a direct contamination source of lead and other pollutants and alter the environmental values of mine tailing contamination. Based on a complete census of the four selected communities (207 children), we conducted a sampling 
of the children ranging above 6 months and until 12 years old with a total of 180 children that comprise 139 and 41 in near and far communities, respectively. Children under 6 months old were excluded due to health conditions and parent disapproval. Parents from selected children signed an informed consent approved by the Mexico City-based National Public Health Institute Ethics Committee (R-2014-785-033). Children's consent was not considered in the study; however all children whose parents agreed to participate were accurately explained the objective of the study and the importance of their cooperation.

\subsection{BBL Determination from Human Samples}

Trained nursing personnel took capillary blood samples in fasting conditions from participants after washing the blood-sampling area with soap and water and cleaning the zone with isopropyl alcohol-impregnated sterile gauze. Samples were adequately labeled and stored at $4{ }^{\circ} \mathrm{C}$ before their analysis in the Autonomous University of Guerrero's Geochemical Laboratory of the Regional Earth Sciences School. $\mathrm{PbB}$ was measured with the anodic stripping voltametry-capillary method with Lead-Care equipment, from ESA, laboratories (Chelmsford, MA, USA) as recommended by the Centers for Disease Control (CDC) in Atlanta, Georgia, USA, and the American Academy of Pediatrics (AAP). Equipment detection reliability range is $1.4-65 \mu \mathrm{g} / \mathrm{dL}$. Internal quality control was performed with equipment standards (Lead Care, Blood Control Kit no. \# BC9907-05) with a correlation of 0.95 [14]. Accuracy was also determined using capillary blood and compared by Graphite Furnace Atomic Absorption at a $10 \mu \mathrm{g} / \mathrm{dL}$ value.

\subsection{Collection of Soil Samples and Lead Determination}

Sufficient and homogeneous random samples of soil, water and dust were taken in the child's play areas and in the houses of the different community participants; sampling was conducted according to the Pace Scan manual $[15,16]$. For soil samples, a $10 \mathrm{~cm}$ area was selected and recovered through a shovel until 300-500 g of sample was collected. Soil was recovered in a sealed bag, labelled and homogenously mixed before $\mathrm{Pb}$ determination. Water samples were collected in glass containers by allowing tap water to flow from 3 to $5 \mathrm{~min}$ and then filling the container without leaving air spaces. For dust samples, selected areas were wiped in hard surfaces such as window sills, and wipes were stored and labelled in sealed bags. Soil and dust samples were stored at ambient temperature to avoid bacterial contamination, while water samples were analyzed immediately to obtain accurate results. Subsequently, environmental lead concentrations by anodic stripping voltammetry (ASV) were determined in ppm (detection limit of $0.255 \mathrm{ppm}$ ). An internal quality control was carried out that provided readings comparable with the EPA 239.s method [17]. An internal sample provided by the manufacturer was measured several times to obtain replicated measures of the same sample and to determinate precision and accuracy of the readings. However, samples were also analyzed in collaboration with the ALS chemexlab facility in agreement with the ISO/IEC 17025.

\subsection{Data Analysis}

To assess data quality, consistency, and value plausibility, exploratory analyses were performed with non-transformed $\mathrm{PbB}$ to better-fit normality and homoscedasticity. Mean difference analysis among study groups revealed the most relevant variables. These relevant variables were mainly cooking with glaze-ceramic, age, sex, and distance from mine tailings. Some data collected such as work exposure showed a non-significant difference that was not representative of the model. A multiple linear regression and a logistical model were constructed. The risk of having a high $\mathrm{PbB}$ concentration associated with living near a mining waste site was evaluated with a logistic regression model with PbB cut-off points $\leq 10 \mu \mathrm{g} / \mathrm{dL}$ and $>10 \mu \mathrm{g} / \mathrm{dL}$, according to the Mexican Official Norm. 


\section{Results}

\subsection{Pb Levels in Soil are High in Communities near Mining Waste Tailings}

$\mathrm{Pb}$ levels were measured in soil, dust and water to determine contamination sources in the selected communities. Pb levels in soil ranged between 1 and 1480 ppm, and in dust between 1 and 209 ppm. In agreement, a significantly higher lead concentration in soil samples of A and B communities was observed as well as in dust samples in community B (Table 1) ( $p>0.05)$. Lead concentrations in water in the four communities were $<2 \mu \mathrm{g}$ per liter; however, in some soil and dust samples lead concentrations were under the detection limit $(25 \mu \mathrm{g} /$ sample), giving a total of 7 below-detection limit samples. One limitation of this study was not obtaining soil and dust samples from all homes of children participating in the study or representative samples. Nonetheless, we have evidence from the preliminary laboratory studies of the same place, in which up to $6620 \mathrm{ppm}$ of lead in tailings were detected in a mean of 3640 ppm [16]; in cultivated soil and school playgrounds, Pb ranged from 88.5 to 2283 ppm [16], all of which represents potential sources of environmental lead contamination.

Table 1. Lead concentration in environmental samples of populations near mining waste sites.

\begin{tabular}{|c|c|c|c|c|}
\hline \multirow[t]{2}{*}{ Environmental Samples } & \multicolumn{3}{|c|}{$\begin{array}{c}\text { Exposed } \\
\text { GM (range) }\end{array}$} & \multirow{2}{*}{$\begin{array}{c}\text { Non-Exposed } \\
\text { GM (range) } \\
\text { D }\end{array}$} \\
\hline & A & B & $\mathrm{C}$ & \\
\hline Distance from mining waste sites $(\mathrm{km})$ & $0.1<5$ & $0.2<5$ & $5-10$ & $>35$ \\
\hline Soil (ppm) & $\begin{array}{c}32.2(1,1480) \\
n=7\end{array}$ & $\begin{array}{c}6.9(1,284) \\
n=14\end{array}$ & $\begin{array}{c}2.1(1,47) \\
n=5\end{array}$ & $\begin{array}{c}2.1(1,47) \\
n=5\end{array}$ \\
\hline Water $(\mu \mathrm{g} / \mathrm{L})$ & $\begin{array}{c}2.0(2,2) \\
n=6\end{array}$ & $\begin{array}{c}1.8(1,2) \\
n=7\end{array}$ & $\begin{array}{c}2.0(2,2) \\
n=4\end{array}$ & $\begin{array}{c}2.0(2,2) \\
n=7\end{array}$ \\
\hline
\end{tabular}

\subsection{BLL Comparison in Near and Far Communities from Waste Tailings}

Blood samples were obtained from 115 children in the communities A, B and C and 41 children in the far community (D); the average ages among children were 6.7 (3.4) years and 6.3 (3.3) years, respectively, without significant differences ( $p>0.05$ ) (Figure 2). Geometric mean (GM) was $10.5 \mu \mathrm{g} / \mathrm{dL}$ ( 0.7 to 33.0 range) for the near communities and $5.5 \mu \mathrm{g} / \mathrm{dL}$ (0.7 to 15.4 range) in the non-exposed children from D community.

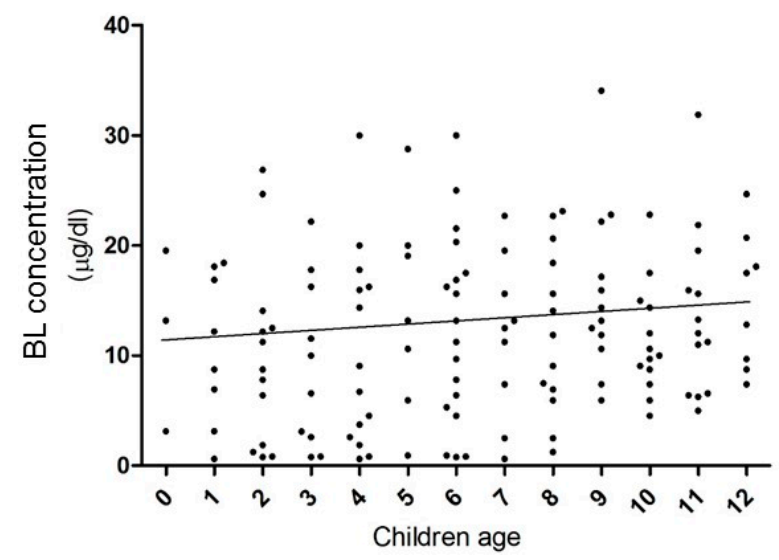

Figure 2. Blood lead levels in terms of age.

GM and BL ranges were higher in communities A and B closer to the mining waste sites $(p>0.05)$ : $\mathrm{GM}$ and range values for community A were $13.6 \mu \mathrm{g} / \mathrm{dL}$ (2.0 to $26.3 \mathrm{BLL}$ range), Community $\mathrm{B}$ contained $15.9 \mu \mathrm{g} / \mathrm{dL}$ of lead in blood (9.0 to 33.0), and community C resulted with $5.5 \mu \mathrm{g} / \mathrm{dL}$ (0.7 to 28). In similarity to community $C$, the furthest from the mining waste, community D had 
$5.5 \mu \mathrm{g} / \mathrm{dL}$ ranging from 0.7 to $15.4 \mathrm{GM}$ and BLL values, respectively. Thus, by a linear regression model comparing distance from the communities to the mining waste site, the communities localized near to the mining tailings had greater BL values in comparison with far communities.

\subsection{Age Influence in Lead Concentrations}

BLL increased linearly with the children's age in comparison with the community situated further from waste sites; however, we observed that BLL GM was higher in boys and girls above 6 years old from A and B communities who attended school located near mining waste sites and where glazed ceramic ware was used for cooking (Figure 1). No statistical differences were observed by gender factor within each community, but we did observe differences within community A among children $<6$ years of age $(p<0.05$, Student $t$ test). GM differences of BLL in far communities were only affected and increased significantly with the use of lead-glazed ceramics and in school attending children (Table 1) $(p>0.05)$.

\subsection{Occupational and Other Variations that Affect Lead Concentration}

During the study, a metal artisan workshop within the home was identified as an additional source of lead-exposure in the homes of some study children; these workshops utilize lead solder, reflected in GM of BLL (Table 2). In bivariate analysis, we found that cooking with lead-glazed ware correlated with $4 \%$ of BLL variability in children. A multiple linear regression model was constructed that included lead-glazed ceramics, sex, age, and community in which children whose homes housed metal workshops were excluded. This model explained $41 \%$ of BLL level variability (Table 3 ). We also observed that the increase in BLL was associated with living near mining waste deposits (Table 3). In a logistic regression, odds ratios (ORs) of children with BLL $>10 \mu \mathrm{g} / \mathrm{dL}$ in exposed communities residing nearest to mining waste deposits were 7.3 (95\% CI 2.1, 25.1) for community A and 80.5 $(95 \%$ CI 9.7, 665.9) for community B, while OR for community C, the exposed community furthest from mining waste sites, was 0.7. In this model, only ORs for elevated BLL in communities A and B differed significantly from community D (Table 4). Variables of sex, age, and cooking in lead-glazed ceramic ware, with which the model was adjusted, were not statistically significant $(p>0.05)($ Table 4$)$.

Table 2. Average blood lead concentration $(\mu \mathrm{g} / \mathrm{dL})$ of exposed and non-exposed child communities to mining waste sites, Taxco, Guerrero, Mexico, 2000.

\begin{tabular}{|c|c|c|c|c|}
\hline Groups * & $\begin{array}{c}\text { Exposed } \\
\text { GM (95\% CI) } \\
\text { A } \\
n=27\end{array}$ & $\begin{array}{c}\text { В } \\
n=59\end{array}$ & $\begin{array}{c}\mathrm{C} \\
n=29\end{array}$ & $\begin{array}{c}\text { Non Exposed } \\
\text { GM (95\% CI) } \\
\text { D } \\
n=41\end{array}$ \\
\hline Total group ${ }^{a}$ & 13.6(10.6, 17.4) & $15.9(14.7,17.2)$ & $5.5(3.9,7.7)$ & $5.5(4.1,7.4)$ \\
\hline Girls ${ }^{\mathrm{b}}$ & $14.9(11.5,19.3)$ & $15.6(14.1,17.3)$ & $5.1(3.3,7.6)$ & $5.5(3.3,9.1)$ \\
\hline Boys ${ }^{b}$ & $11.2(6.1,20.8)$ & $16.2(14.2,18.4)$ & $5.3(2.7,10.2)$ & $4.6(2.6,8.1)$ \\
\hline$<6$ years of Age ${ }^{b}$ & $10.8(7.2,16.4)$ & $16.1(14.2,18.1)$ & $5.2(2.1,12.8)$ & $3.7(2.1,6.7)$ \\
\hline$\geq 6$ years of Age ${ }^{b}$ & $18.0(15.5,20.9)$ & $15.8(14.2,17.6)$ & $5.6(3.9,8.2)$ & $7.1(5.3,9.7)$ \\
\hline \multicolumn{5}{|l|}{$\begin{array}{l}\text { Use of glazed } \\
\text { ceramics }\end{array}$} \\
\hline Yes $^{a}$ & $15.8(12.8,19.6)$ & $16.0(14.5,17.6)$ & $5.2(3.2,8.5)$ & $8.1(6.7,9.8)$ \\
\hline $\mathrm{No}^{\mathrm{a}}$ & $10.2(5.5,18.9)$ & $15.7(13.2,18.6)$ & $4.8(1.7,13.2)$ & $2.0(0.8,5.0)$ \\
\hline \multicolumn{5}{|l|}{ Attends school } \\
\hline Yes ${ }^{b}$ & $14.2(9.7,20.8)$ & $15.9(14.4,17.5)$ & $6.0(3.9,9.2)$ & $8.1(6.41,10.2)$ \\
\hline No ${ }^{b}$ & $12.6(8.5,18.9)$ & $15.9(14.1,17.9)$ & $2.8(0.7,11.2)$ & $2.0(0.7,5.3)$ \\
\hline \multicolumn{5}{|l|}{ Home workshop } \\
\hline Yes $^{a}$ & $18.3(14.1,23.8)$ & $17.3(15.0,20.0)$ & - & - \\
\hline $\mathrm{No}^{\mathrm{a}}$ & $12.4(9.1,17.0)$ & $15.2(13.8,16.8)$ & $5.1(3.3,7.7)$ & $4.9(3.3,7.3)$ \\
\hline
\end{tabular}


Table 3. Blood lead predictors ${ }^{1}$ of exposed and non-exposed children to mining waste sites.

\begin{tabular}{lccc}
\hline Variables & Coefficients & $\mathbf{9 5 \%} \mathbf{C I}$ & $p>\mathbf{t}$ \\
\hline Cooking in glazed ceramics $^{\mathrm{b}}$ & 1.9 & $-0.3,4.1$ & 0.193 \\
Sex (feminine) $^{\mathrm{b}}$ & -0.9 & $-2.8,1.1$ & 0.362 \\
Age $^{\mathrm{a}}$ & 0.4 & $0.1,0.7$ & 0.009 \\
Community A $^{\mathrm{b}}$ & 8.2 & $5.2,11.1$ & 0 \\
Community B $^{\mathrm{b}}$ & 8.1 & $5.5,10.6$ & 0 \\
Community C $^{\mathrm{b}}$ & -0.3 & $-2.9,2.4$ & 0.848 \\
Constant $^{1} \mathrm{gg} / \mathrm{dL}^{\text {a }}$ continuous variables; $^{\mathrm{b}}$ dichotomous variables; $95 \%$ CI, $95 \%$ confidence interval. $n=130 ; R^{2}=0.41$.
\end{tabular}

Table 4. Blood lead ${ }^{1}$ with cut-off points $\leq 10 \mu \mathrm{g} / \mathrm{dL}$ and $>10 \mu \mathrm{g} / \mathrm{dL}$ in children.

\begin{tabular}{lcc}
\hline Community & OR & $\mathbf{9 5 \%}$ CI \\
\hline Community A & 7.3 & $2.1,25.1^{\mathrm{a}}$ \\
Community B & 80.5 & $9.7,665.9^{\mathrm{a}}$ \\
Community C & 0.7 & $0.2,2.1$ \\
Cooking in glazed ceramics & 1.7 & $0.6,4.8$ \\
Sex (feminine) & 1 & $0.4,2.6$ \\
Age & 1.1 & $0.9,1.3$ \\
\hline$\mu \mathrm{g} / \mathrm{dL} ;$ OR, odds ratio; $95 \% \mathrm{CI}, 95 \%$ confidence interval. $n=130 ;^{\mathrm{a}} p<0.05$.
\end{tabular}

BLL in all children residing near mining waste deposits was higher than of the non-exposed community (10.5 and $5.5 \mu \mathrm{g} / \mathrm{dL}$, respectively) $(p>0.05)$. When we stratified the communities according to distance between community domiciles and mining waste sites, we found a GM of BLL concentration in community $\mathrm{A}=13.6 \mu \mathrm{g} / \mathrm{dL}$ (range, 2.0 to 26.3 ) and in community $\mathrm{B}, 15.9 \mu \mathrm{g} / \mathrm{dL}$ (range, 9.0 to 33.0), different from community $C$ that was further from the mining waste deposits, with $5.5 \mu \mathrm{g} / \mathrm{dL}$ (range, 0.7 to 28) and non-exposed community (D) with $5.5 \mu \mathrm{g} / \mathrm{dL}$ (range, 0.7 to 15.4) (Table 2). Our study provides evidence that children living near mining waste sites within rural communities of the Taxco, Guerrero, Mexico mining zone have $8.0 \mu \mathrm{g} / \mathrm{dL}$ higher average BLL in comparison with children in non-exposed communities (Table 3) $(p>0.05)$; this increase is higher than the contribution made by the use of lead-glazed ceramics. We also observed that as age of children increased, so did their BLL; this is perhaps because school-age children have greater contact with soil contamination at educational centers and play areas as shown in results of boys and girls who attended school (Table 2). Greater exposure and bioavailability of lead in mining wastes is also seen in the high percentage of BLL; $>10 \mu \mathrm{g} / \mathrm{dL}$ in children corresponding to A and B communities ( $72.7 \%$ and $97.5 \%$, respectively). Likewise, in a study of 20 children residing near other mining waste sites deposited near the city of Taxco, we found a GM of BLL of $12.7 \mu \mathrm{g} / \mathrm{dL}$ [18], a very similar concentration to that observed in communities A and B in our study. In the present study, GM was $11.1 \mu \mathrm{g} / \mathrm{dL}$ in children $<6$ years of age $(n=43)$ exposed to mining waste, while in children of the same age but who were non-exposed $(n=17)$, GM of BLL was $3.7 \mu \mathrm{g} / \mathrm{dL}$. Children $\geq 6$ years of age $(n=72)$ had a GM of $12.1 \mu \mathrm{g} / \mathrm{dL}$, and among non-exposed children $(n=24)$ in the same age group GM was $7.1 \mu \mathrm{g} / \mathrm{dL}$.

\section{Discussion}

Some studies show that environmental lead contamination sources (mines, smelters) may affect soil, water, air, and food that subsequently increase the blood lead levels of local residents [19]. In agreement, in this work we observed that children living in communities near the waste of the mine had higher BLL than children far from the mining wastes. These results were similar to other studies [9-13]. Exposure pathways in the communities may include particulate matter in the air and contaminated soil and dust in homes; however, although dust and soil samples were not necessarily representative of the communities, there is a clear tendency of a high lead concentration located in 
communities with greater proximity to mining waste sites. It is noteworthy that some dust samples were observed below the detection limit, indicating that the main contamination sources were soil and use of lead-glazed ceramics. In regards to water lead levels determination, we sampled without stagnation to have a homogenous sample of the water deposits that flow through the communities without an interference on the faucet conditions. Several studies in Mexico City highlight lead-exposure sources such as lead-glazed earthenware and vehicular traffic. In one work, BLL ranges from 3.5 to 25.2 and determines vehicular traffic as the predominant cause of BLL increase [20]. Another study developed in the southern area of Mexico City [21,22] observed that $44 \%$ of the samples analyzed exceeded $10 \mu \mathrm{g} / \mathrm{dL}$ with vehicular traffic and use of lead-glazed ceramics for cooking as the main contamination sources. In Mexico, tetraethyl and tetramethyl lead were classified as toxic additive fuel since 1993 and forbidden. Measurement of lead levels in air showed an increase in highly dense areas. However, according to comparative results the amount of lead pollution in air is constantly decreasing. We have found that, comparable with vehicular traffic and lead glaze ceramics as contamination sources, mining waste contributes to increased BLL in resident children and in those exposed to lead by means of soil and dust. Interestingly, there are some studies that indicate non-common contamination sources. In the U.S., a slow decline in BLL has been observed in the age group of <2 years 1976 and 1994 [23]; however, in May 2001, Californian and Food and Drug Administration (FDA) officials found BLL of $40-50 \mu \mathrm{g} / \mathrm{dL}$ in some children. Interestingly, the FDA observed lead in a common ingredient (chili powder) of many Mexican candies that happened to agree with the BLL of children that consumed tamarind candies [24].

Mean blood lead levels are very diverse and range from $3.1 \mu \mathrm{g} / \mathrm{dL}$ [9] to $17.0 \mu \mathrm{g} / \mathrm{dL}$ in non-exposed children. The variety of results in the literature is the consequence of having studied children in various age groups categorized by sex, socioeconomic status, or nutritional level. Likewise, it is necessary to consider the diverse types of mining waste; taking into account their mineral composition, particle size, and the geographic-environmental conditions around communities situated near mine tailings. We should also bear in mind culture-specific habits (use of glazed ceramic ware, use of toys with $\mathrm{Pb}$ containing paint, etc) to explain such variability in findings. Also, we must consider that BLL shows a probable lead contamination that indicates that distance is not enough between the non-exposed community and the mining-waste sites. In other works, control populations are approximately $200 \mathrm{~km}$ far from the mining site. This would indicate that our control group consists of a less exposed group but is also susceptible to lead contamination, supporting the hypothesis that distance from mine tailings influences lead exposure, with near communities more polluted than far communities [23,25]. However, our results agree with the general conclusions described by other studies; thus, mine tailings contribute to an increase of blood lead levels in children.

Although we did not determine the wind blowing in the exposed and non-exposed communities, we observed that the main contamination sources might come from streams originating from the main river. In general, the BLL values in children in all communities, including community D, was high in comparison with other BLL ranges [26]. This result indicates that the environment of the communities is highly contaminated with $\mathrm{Pb}$ that reflects in blood levels. It is necessary to imploy preventive measures and warning strategies to avoid the consecuences of high BLL. It has been reported that an increase of BLL in children is mainly related to cognitive and behavioral complications, besides chronic fatigue, mucous pigmentation, gingivitis, and tongue burning, among others [27]. A constant evaluation of BLL values as well as environmental levels in highly polluted areas will help to control the $\mathrm{Pb}$ sparse throughout the communities and apply preventive measures and a prompt medical response to $\mathrm{Pb}$ contamination [25].

\section{Conclusions}

The present data suggest that mining waste without sanitary control in the mining district of Taxco, Guerrero, Mexico is associated with increased BLL and strongly increased BLL > $10 \mu \mathrm{g} / \mathrm{dL}$ among children with a subsequent increase of risk of adverse health effects. In addition to taking 
substantive measures controlling the use of lead glazed ceramic ware in the kitchen, it is urgent to enforce local legal limits on maximum levels of lead in mining deposits (NOM-157, SEMARNAT 2009) [28] in order to reduce lead exposure of children in nearby communities.

Acknowledgments: This work was partially supported by the CONACYT and the Benito Juarez Investigation System (SIBEJ) grants. The authors are grateful to Patricia A. Cuellar Silva for proofreading the paper and for excellent technical assistance.

Author Contributions: María de Lourdes Soto-Ríos, and Cuauhtémoc Arturo Juárez-Pérez wrote the article; Oscar Talavera-Mendoza, Guadalupe Aguilar-Madrid and Francisco Javier Rendón-Gandarilla performed the sampling work, conducted the experiments, and processed the data.

Conflicts of Interest: The authors declare no conflict of interest.

\section{References}

1. Kianoush, S.; Sadeghi, M.; Balali-Mood, M. Recent advances in the clinical management of lead poisoning. Acta Med. Iran. 2015, 53, 327-336. [PubMed]

2. Beamer, P.; Key, M.E.; Ferguson, A.C.; Canales, R.A.; Auyeung, W.; Leckie, J.O. Quantified activity pattern data from 6 to 27-month-old farmworker children for use in exposure assessment. Environ. Res. 2008, 108, 239-246. [CrossRef] [PubMed]

3. Mohammadi, S.; Mehrparvar, A.; Aghilinejad, M. Appendectomy due to lead poisoning: A case-report. J. Occup. Med. Toxicol. 2008, 3, 23. [CrossRef] [PubMed]

4. Vega-Franco, L.; Alvear, G.; Meza-Camacho, C. Glazed pottery as a risk factor in lead exposure. Salud Publica Mex. 1994, 36, 148-153. [PubMed]

5. Azcona-Cruz, M.I.; Rothenberg, S.J; Schnaas-Arrieta, L.; Romero-Placeres, M.; Perroni-Hernandez, E. Levels of plasmatic lead in children 8-10 years of age and its relation to changes in visual-motor system and balance. Salud Publica Mex. 2000, 42, 279-287. [CrossRef] [PubMed]

6. Kehoe, R.A. Occupational lead poisoning: 2-Chemical signs of the absorption of lead. J. Occup. Med. 1972, 14, 390-396. [PubMed]

7. Bjerre, B.; Berglund, M.; Harsbo, K.; Hellman, B. Blood lead concentrations of swedish preschool children in a community with high lead levels from mine waste in soil and dust. Scand. J. Work Environ. Health 1993, 19, 154-161. [CrossRef] [PubMed]

8. Danse, I.H.; Garb, L.G.; Moore, R.H. Blood lead surveys of communities in proximity to lead-containing mill tailings. Am. Ind. Hyg. Assoc. J. 1995, 56, 384-393. [CrossRef] [PubMed]

9. Rieuwerts, J.S.; Farago, M.E.; Cikrt, M.; Bencko, V. Differences in lead bioavailability between a smelting and a mining area. Water Air Soil Pollut. 2000, 122, 203-229. [CrossRef]

10. Steele, M.J.; Beck, B.D.; Murphy, B.L.; Strauss, H.S. Assessing the contribution from lead in mining wastes to blood lead. Regul. Toxicol. Pharmacol. 1990, 11, 158-190. [CrossRef]

11. Murgueytio, A.M.; Evans, R.G.; Roberts, D. Relationship between soil and dust lead in a lead mining area and blood lead levels. J. Expo. Anal. Environ. Epidemiol. 1998, 8, 173-186. [PubMed]

12. Gulson, B.L.; Mizon, K.J.; Korsch, M.J.; Howarth, D. Importance of monitoring family members in establishing sources and pathways of lead in blood. Sci. Total Environ. 1996, 188, 173-182. [CrossRef]

13. Malcoe, L.H.; Lynch, R.A.; Keger, M.C.; Skaggs, V.J. Lead sources, behaviors, and socioeconomic factors in relation to blood lead of native American and white children: A community-based assessment of a former mining area. Environ. Health Perspect. 2002, 110, 221-231. [CrossRef] [PubMed]

14. Savely, S.M.; Emery, R.J.; Connor, T.H. A comparison of methods for determining lead content in drinking water: A portable anodic stripping voltammetry instrument method versus the standard epa 239.2 method. AIHAJ 2000, 61, 557-562. [CrossRef]

15. Sterling, D.A.; Lewis, R.D.; Luke, D.A.; Shadel, B.N. A portable x-ray fluorescence instrument for analyzing dust wipe samples for lead: Evaluation with field samples. Environ. Res. 2000, 83, 174-179. [CrossRef] [PubMed]

16. Talavera-Mendoza, O. Determination of Bioavailable Metals in Mining Shafts as a Guide to Assess their Potential for Contamination; Memorias del III; Foro de Estudios Sobre Guerrero: Acapulco, Mexico, 2000.

17. PaceScan 3000 TM Operator. Operator Manual Instructions for Using the Pacescan System for Quantitative Analysis of Lead in Paint, Dust, Soil And Drinking Water; Pace Environs, Inc.: Lehigh Valley, PA, USA, 1997. 
18. Soto-Ríos, M.J.C.; Talavera, O.; Aguilar, G.; Rothenberg, S. Living near mining waste is associated with higher blood lead concentrations in children. In Proceedings of the Memories International Worshop, Buenos Aires, Argentina, 29-30 August 2005.

19. Meza-Figueroa, D.; Maier, R.M.; de la, O.V.M.; Gomez-Alvarez, A.; Moreno-Zazueta, A.; Rivera, J.; Campillo, A.; Grandlic, C.J.; Anaya, R.; Palafox-Reyes, J. The impact of unconfined mine tailings in residential areas from a mining town in a semi-arid environment: Nacozari, Sonora, Mexico. Chemosphere 2009, 77, 140-147. [CrossRef] [PubMed]

20. Jimenez, C.; Romieu, I.; Palazuelos, E.; Munoz, I.; Cortes, M.; Rivero, A.; Catalan, J. Environmental exposure factors and the concentrations of blood lead in Mexico city children. Salud Publica Mex. 1993, 35, 599-606. [PubMed]

21. Romieu, I.; Carreon, T.; Lopez, L.; Palazuelos, E.; Rios, C.; Manuel, Y.; Hernandez-Avila, M. Environmental urban lead exposure and blood lead levels in children of Mexico city. Environ. Health Perspect. 1995, 103, 1036-1040. [CrossRef] [PubMed]

22. Schnaas, L.; Rothenberg, S.J.; Flores, M.F.; Martinez, S.; Hernandez, C.; Osorio, E.; Perroni, E. Blood lead secular trend in a cohort of children in Mexico city (1987-2002). Environ. Health Perspect. 2004, 112, 1110-1115. [CrossRef] [PubMed]

23. Mattuck, R.L.; Beck, B.D.; Bowers, T.S.; Cohen, J.T. Recent trends in childhood blood lead levels. Arch. Environ. Health 2001, 56, 536-541. [CrossRef] [PubMed]

24. Medlin, J. Sweet candy, bitter poison. Environ. Health Perspect. 2004, 112, A803. [CrossRef] [PubMed]

25. Jasso-Pineda, Y.; Diaz-Barriga, F.; Calderon, J.; Yanez, L.; Carrizales, L.; Perez-Maldonado, I.N. DNA damage and decreased DNA repair in peripheral blood mononuclear cells in individuals exposed to arsenic and lead in a mining site. Biol. Trace Elem. Res. 2012, 146, 141-149. [CrossRef] [PubMed]

26. Paoliello, M.M.; De Capitani, E.M. Occupational and environmental human lead exposure in Brazil. Environ. Res 2007, 103, 288-297. [CrossRef] [PubMed]

27. Jalili, M.; Azizkhani, R. Lead toxicity resulting from chronic ingestion of opium. West. J. Emergency Med. 2009, 10, 244-246.

28. Mexicana, N.O. Nom-157-semarnat-2009. Diario Oficial de la Federación. 2011. Available online: http:/ / www.dof.gob.mx/normasOficiales/4485/semarnat1/semarnat1.htm (accessed on 2 June 2017).

(C) 2017 by the authors. Licensee MDPI, Basel, Switzerland. This article is an open access article distributed under the terms and conditions of the Creative Commons Attribution (CC BY) license (http:/ / creativecommons.org/licenses/by/4.0/). 